\title{
огляди
}

UDC 543.635.24:616.15:616-008.846.1-074/-076

\section{“THREE SOURCES AND THREE COMPONENT PARTS” OF FREE OLIGOSACCHARIDES}

\author{
I. U. PISMENETSKAYA 1 , T. D. BUTTERS ${ }^{2}$ \\ ${ }^{1}$ SI Dnepropetrovsk Medical Academy, Ukraine; \\ ${ }^{2}$ Oxford Glycobiology Institute, University of Oxford, UK; \\ e-mail: pismenetskaya@yahoo.com
}

Metabolism of glycoproteins and glycolipids is accompanied by the appearance of unbound structural analogues of the carbohydrate portion of glycoconjugates or so called free oligosaccharides. There are their several sources inside the cell: 1) multistep pathways of N-glycosylation, 2) the cell quality control and ER-associated degradation of misglycosylated and /or misfolded glycoproteins, 3) lysosomal degradation of mature glycoconjugates. In this review the information about the ways of free oligosaccharides appearance in different cell compartments and details of their structures depending on the source is summarized. In addition, extracellular free oligosaccharides, their structures and changes under normal and pathological conditions are discussed.

Key word s: free oligosaccharides, dolichol phosphate cycle, ER-associated protein degradation, lysosomal degradation, blood plasma, urine.

G lycosylation is one of the most widespread post- and co-translational modifications of proteins and lipids. All the functional roles of the enormous diversity of glycan structures are not known but there is no doubt about their crucial importance in essential molecular processes maintaining development, maturation and continuing health of living organisms. An aberrant glycosylation in different disorders is a proof of that. Metabolism of glycoconjugates is accompanied by the appearance of unbound structural analogues of the carbohydrate portion of glycoconjugates or free oligosaccharides (FOS).

Free oligosaccharides are the combined results of three main processes (multistep pathways of $\mathrm{N}$ - linked glycosylation itself, ER-associated degradation (ERAD) of misglycosylated and/or misfolded glycoproteins and lysosomal degradation of mature glycoconjugates) [1-3] and can indicate normal and aberrant pathways of previous and current glycosylation. Some of these FOS are the earliest indicators of potential glycosylation alterations that would be revealed in the course of the cell quality control and ER-associated degradation. The connection between FOS detection and human disorders has been demonstrated and glucosylated FOS have been revealed as quantifiable biomarkers of ER-glucosidase inhibition in vivo and quite informative in lysosomal storage disorders [4]. Certain enzyme deficiencies in the case of congenital disorders of glycosylation

\footnotetext{
Abbreviations: BiP - immunoglobulin heavy-chain-binding protein; Derlin - degradation in endoplasmic reticulum protein; DnaJ - heat shock proteins with J-domain; EDEM - ER-degradation enhancing alpha-mannosidase like protein; ENGase - endo- $\beta$-N-acetylglucosaminidase; ERAD (ER-associated degradation) - endoplasmic reticulum-associated degradation; ERp57, ERp59, ERp72, ERp44 - disulfide-isomerase like proteins in ER; $\alpha$-GII - $\alpha$-glycosidase II; GM1, GM2 - monosialotetrahexosyl-gangliosides; GRP78 - glucose regulated protein; HPLC - high performance liquid chromatography; Hsp70, Hsp40 - heat shock proteins; MALDI-TOF MS - matrix-assisted laser desorption/ ionization time-of-flight mass spectrometry; MAN1B1 (endomannosidase I) - $\alpha(1,2)$-mannosidase; NAM (MAN2C1) neutral cytosolic $\alpha$-mannosidase; PDI - protein disulphide isomerise; PNGase - peptide:N-glycanase; UGGT - UDPglucose:glycoprotein glucosyltransferase.
} 
are sufficiently reflected in the FOS structures [5]. Oncotransformations can dramatically change FOS profiles in urine of patients with hepatocellular carcinoma [6] and plasma of patients with blood proliferative diseases [7]. Thus, free oligosaccharides have to reflect a general glycostatus of a cell or an organism.

In this review we will analyse the information known so far about the ways of FOS appearance, their structures, intracellular compartmentalization and extracellular distribution.

\section{Dolichol phosphate cycle at the early stage of $\mathbf{N}$-glycosylation gives rise mostly to negatively charged phosphorylated free oligosaccharides}

Dolichol (Dol) is a polyisoprenoid alcohol used as a sugar carrier for $\mathrm{N}$-glycosylation both in the endoplasmic reticulum and the Golgi. In ER it takes part at the early stage of $\mathrm{N}$-glycosylation step-by-step assembling the precursor glycan $\mathrm{Glc}_{3} \mathrm{Man}_{9} \mathrm{GlcNAc}_{2}$. To become the carrier in an eukaryotic cell it must be phosphorylated by dolichol kinase (EC 2.7.1.108) to form dolichol phosphate (Dol-P) [8].

Dolichol phosphate is biosynthesized on the cytoplasmic face of the endoplasmic reticulum and the precursor glycan assembling begins on the same side (Fig. 1).

Sugar residues from nucleotide-activated sugar donors are transferred onto a dolichol phosphate by specific cytoplasmically oriented glycosyltransferases. In the first reaction, GlcNAc-P is moved from uridine diphosphate $\mathrm{N}$-acetylglucosamine (UDPGlcNAc) onto Dol-P giving rise to GlcNAc-PP-Dol with the aid of $\mathrm{N}$-acetylglucosamine transferase (EC 2.7.8.15). In the second reaction, another GlcNAc residue is added to the structure. In the following metabolic steps, specific mannosyltransferases (EC 2.4.1.142; EC 2.4.1.132; EC 2.4.1.257; EC 2.4.1.131) add five Man from guanosine diphosphate mannoses (GDP-Man) to the growing saccharide till generation of the heptasaccharide $\mathrm{Man}_{5} \mathrm{GlcNAc}_{2}$-PP-Dol. At this point the synthesis of the glycans-precursors on the cytoplasmic side of ER membrane is finished and the heptasaccharide is flipped across the ER membrane to the luminal face.

Inside the lumen mannosyltransferases (EC 2.4.1.258; EC 2.4.1.259; EC 2.4.1.261; EC 2.4.1.260) transfer Man from Dol-P-Man to the oligosaccharide elongating the glycan till Man ${ }_{9}$ Glc$\mathrm{NAc}_{2}$-PP-Dol. The formation of the glycan-pre- cursor ends by addition of three glucose residues from Dol-P-Glc with the aid of glucosyltransferases (EC 2.4.1.267; EC 2.4.1.265; EC 2.4.1.266). Dol-P-Man and Dol-P-Glc are synthesized on the cytosolic side of ER membrane and then flipped into the lumen.

When the precursor oligosaccharide is transferred from Glc $_{3} \mathrm{Man}_{9} \mathrm{GlcNAc}_{2}$-P-P-Dol to appropriate Asn-X-Ser/Thr sequences in nascent polypeptides in the lumen of the endoplasmic reticulum, the glycosyl carrier lipid is released as dolichol pyrophosphate (Dol-P-P). A Dol-P-P phosphatase (EC 3.6.1.43) converts Dol-P-P to Dol-P [9]. Dol-P returns to the cytoplasmic side of ER where it can be reutilized for lipid intermediate biosynthesis and additional rounds of $\mathrm{N}$-glycosylation [10].

Dol-P is a rate-limiting intermediate during protein N-glycosylation [11]. Because de novo dolichol synthesis is slow, Dol-P availability from the dolichol cycle being of particular importance may demand recycling of mature [12] and even immature [13] Dol-P-oligosaccharide intermediates that leads to appearance of free oligosaccharides as byproducts. There are two principal ways of their formation: by cleaving the bond between two residues of phosphoric acid or by breaking the linkage between the second residue of the acid and GlcNAc. The first way leads to releasing of free glycans with a negative charge due to one residue of phosphoric acid at the reducing end of the sugars (Fig. 1, A, B). A realization of the different possibility gives rise to neutral free oligosaccharides with $\mathrm{N}$-acetylglucosamine at the reducing termini (Fig. 1, $C, D$ ). Interestingly, some Dol-P-oligosaccharide intermediates are a source of only the first group of FOS, others form the second, and there are some intermediates that may give the both.

The first evidence that the dolichol cycle is the source of free phosphooligosaccharides was obtained by Hsu et al. during the elucidation of the role of Man-P-Dol in the protein glycosylation. In mouse myeloma microsomes the researchers revealed free $\mathrm{Man}_{5} \mathrm{GlcNAc}_{2}-\mathrm{P}$ [14]. The presence of free Man ${ }_{9}$ Glc$\mathrm{NAc}_{2}-\mathrm{P}$ was demonstrated in rat spleen lymphocytes [15]. $\mathrm{Man}_{2-9} \mathrm{GlcNAc}_{2}-\mathrm{P}$ were detected in many cell lines [16]. Further investigations revealed the pyrophosphatase (EC 3.6.1.44) hydrolysing the diphosphate bond that leads to formation of phosphorylated oligosaccharides [17] and the different fates of intermediates from the pool of Dol-P-oligosaccharides: the non-glucosylated ones gave rise to free phosphooligosaccharides but glucosylated led to appearance 


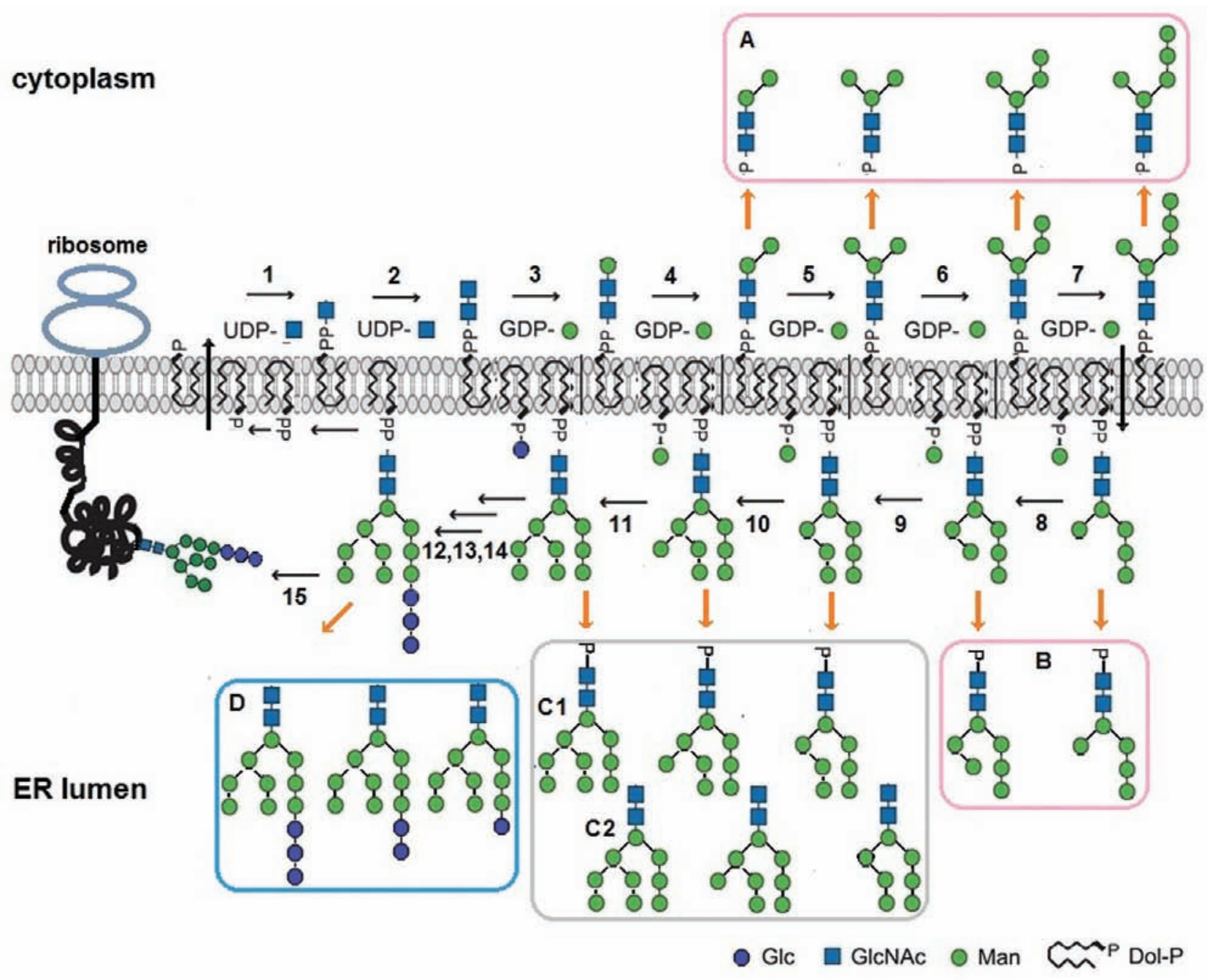

Fig. 1. The dolichol phosphate cycle as a source of free oligosaccharides. UDP - uridine diphosphate, GDP guanosine diphosphate, $P$ - phosphate, $P P$ - pyrophosphate, Glc - glucose, GlcNAc - N-acetylglucosamine, Dol-P - dolichol phosphate; 1 - UDP-GlcNAc: dolichol phosphate GlcNAc-1-phosphate transferase; 2 - UDPGlcNAc: dolichol pyrophosphate-GlcNAc N-acetylglucosaminyltransferase; 3-chitobiosyldiphosphodolichol $\beta$-mannosyltransferase ; 4,5- $\alpha-1,3$ mannosyltransferase; 6,7 - $\alpha-1,2$-mannosyltransferase; 8 -Dol-P-Man: $\mathrm{Man}_{5}$ GlcNAC $_{2}-P P$-Dol mannosyltransferase; 9,11 - Dol-P-Man: Man ${ }_{6(8)}$ GlcNAc2-PP-Dol mannosyltransferase; 10 - Dol-P-Man: Man ${ }_{7} G l c N A c_{2} P P$-Dol mannosyltransferase; 12 - $\alpha$-1,3-glucosyltransferase I; 13 $\alpha$-1,3-glucosyltransferase II; $14-\alpha-1,2$-glucosyltransferase; $\mathbf{1 5}$ - oligosaccharyltransferase; $\boldsymbol{A}$ - cytosolic phosphorylated charged FOS; B - intralumenal phosphorylated charged FOS; $\boldsymbol{C}$ - phosphorylated charged (1) and neutral (2) FOS from the same Dol-P-oligosaccharide intermediates; $\boldsymbol{D}$-glucosylated neutral FOS

of free neutral oligosaccharides or were utilised in protein glycosylation [18].

When the genes coding the proteins involved in the dolichol cycle are defective and the cycle is interrupted, hypoglycosylation of glycoproteins leads to development of congenital disorders of glycosylation type I (CDG I), rare multisystem genetic diseases affected nearly all organs and tissues [19]. In these cases the concentration of truncated Dol-
P-oligosaccharides, substrates of limiting reactions and corresponding free oligosaccharides increase dramatically [20]. Investigations of Epstein-Barr virus-transformed lymphoblasts derived from a healthy subject and patients with different types of CDG-I showed low levels of the FOS in normal cells and elevated accumulation in CDG-derived cells. In CDG-Ig cells (with a mutation in the $\alpha 1,2$ mannosyl transferase - EC 2.4.1.259, EC 2.4.1.261- adding the 
seventh mannose residue to oligosaccharide precursor) negatively charged components increased 3 fold with respect to the control. Interestingly, this study revealed only the species with 7 and less mannose residues among phosphorylated oligosaccharides. Moreover, the analysis of ER luminal and cytosolic phosphorylated FOS detected the appearance of species with 7 mannose residues exclusively in the cytosol. This finding prompted the proposal of an ER-tocytosol translocation way for $\mathrm{Man}_{6-7} \mathrm{GlcNAc}_{2}-\mathrm{P}$ [11].

Phosphorylated oligosaccharides can be released from dolichol phosphate by the action of pyrophosphatase (EC 3.6.1.44) at the cytosolic face of the endoplasmic reticulum [18]. Removal of the phosphate from the phosphorylated glycans converts them into oligomannose structures with two GlcNAc residues.

The formation of neutral free oligosaccharides from dolichol pyrophosphate oligosaccharides was shown in the beginning in pig liver [21], hen oviduct [22] and calf thyroid microsomes [12]. The oligosaccharides had the glucose-containing oligomannose structure with two GlcNAc residues at the reducing end $-\mathrm{Glc}_{3} \mathrm{Man}_{9} \mathrm{GlcNAc}_{2}$. The investigations led to the idea that the oligosaccharyl transferase (EC 2.4.1.119) could carry out both the hydrolytic and transfer functions. The authors speculated that when acceptor polypeptides were limiting, the enzyme could transfer the mature glycan precursor from the lipid carrier onto water molecules generating neutral FOS. For a long time no direct experimental evidence supporting or rejecting the hypothesis had been presented. Only recently [23], using mutant strains of Saccharomyces cerevisiae, the hydrolytic activity of the enzyme has been proved. To great surprise it turned to be connected with the presence of a hydrolytic active centre in addition to the transferase centre rather than the acceptor limitation. It means that the oligosaccharyl transferase catalyses both reactions in-parallel. More truncated glycans, $\mathrm{Man}_{7-9} \mathrm{GlcNAc}_{2}$, were also found in the ER lumen [24, 25]. The neutral free oligosaccharides are translocated from ER into the cytosol. However, their contribution to the dolichol cycle-derived FOS as well as to the total pool of free neutral oligosaccharides originating from the ER to the cytosol is not significant, since the major source is from misfolded/ misassembled glycoproteins, the subjects of ERAD $[4,26,27]$.

Thus, in fact there are two cycles of dolichol phosphate. The first gives rise to phosphorylated free oligosaccharides with 2-7 mannose residues, the second - to neutral free oligosaccharides with 7-9 mannose residues as well as glucosylated oligomannose structures.

\section{ER-associated protein degradation (ERAD) releases glucosylated and non-glucosylated oligomannose free oligosaccharides}

Following transfer of the glycan from lipid-precursor to a nascent polypeptide, $\alpha$-glycosidases I and II (EC 3.2.1.106; EC 3.2.1.84) remove two glucose residues and the oligomannose glycans with one glucose residue connects to calnexin or calreticulin allowing the glycoprotein to enter the calnexin/calreticulin cycle to be completely folded and assembled with the help of the chaperone system BiP/GRP78 or Hsp70, BiP cochaperones (DnaJ/Hsp40 family members - $\mathrm{ERdj}_{1-7}$ ), protein disulphide isomerases (PDI, ERp57, ERp59, ERp72, ERp44 - EC 5.3.4.1) and some substrate-specific chaperones [28]. $\alpha$-Glucosidase II (EC 3.2.1.84) cuts the last residue of glucose and a correctly folded glycoprotein leaves the cycle moving to the Golgi for further processing. An aberrant glycoprotein can be retained for a while in ER due to tandem actions of $\alpha$-glycosidase II ( $\alpha$-GII) and UDP-glucose:glycoprotein glucosyltransferase (UGGT, EC 3.6.5.3), which transfers one glucose residue again to the glycan and allows the glycoprotein to return to calnexin/calreticulin cycle, or can be sent to the ER - associated degradation due to action of ER $\alpha$-mannosidase I (EC 3.2.1.113), EDEM (EC 3.2.1.24; EC 3.2.1.113) or Golgi-resident MAN1B1 (3.2.1.113), which remove one mannose residue from $\mathrm{Man}_{9} \mathrm{GlcNAc}_{2}$ and forms $\mathrm{B}$ isomer of $\mathrm{Man}_{8} \mathrm{GlcNAc}_{2}$ on the aberrant glycoprotein [29, 30] or trim the glycans more extensively giving rise to $\mathrm{Man}_{7} \mathrm{GlcNAc}_{2}$, Man $_{6} \mathrm{GlcNAc}_{2}$ and $\mathrm{Man}_{5} \mathrm{GlcNAc}_{2}$ [31].

$\alpha$-Glucosidase II is a unique enzyme with a dual biochemical function. On the one hand, it provides transfer of glycoproteins to and from the calnexin/calreticulin cycle, on the other hand, it can send them further either to the Golgi or to the cytosol for degradation. $\alpha$-GII is a luminal glycoprotein and consists of a catalytic $\alpha$ and a regulatory $\beta$ subunits. The latter is responsible for the endoplasmic reticulum localization of the heterodimer and for the enhancement of $\mathrm{N}$-glycan trimming. It is not clear in detail what forces GlcMan ${ }_{9} \mathrm{GlcNAc}_{2}$, the product of the first reaction of the enzyme, to leave the active centre and move to calnexin or calreticulin. The rate 
of the first reaction, Glc $\alpha 1-3$ Glc cleavage, in the early investigations seemed to be higher than that of the second, Glca1-3Man hydrolysis. The later findings, however, showed that the second reaction essentially enhanced at the high protein concentrations that in fact take place in ER. Nevertheless, a high competition with calnexin/calreticulin for the substrate and strong suppression of the enzyme's second reaction by calreticulin have been revealed. The glucosidase has a surprisingly wide range of substrates that in addition to $\mathrm{Glc}_{2} \mathrm{Man}_{9} \mathrm{GlcNAc}_{2}$ and GlcMan $\mathrm{GlcNAc}_{2}$ includes GlcMan ${ }_{8} \mathrm{GlcNAc}_{2}$ and GlcMan $\mathrm{GlcNAc}_{2}$. The enzyme can be inhibited by its nonglucosylated end products - Man ${ }_{9}$ GlcNAc $_{2}, M_{8}$ GlcNAc $_{2}$ and $\mathrm{Man}_{7} \mathrm{GlcNAc}_{2}$. The latter is the strongest inhibitor and its effect can be even comparable with those of such powerful inhibitors of glucosidases as castanospermine and deoxynojirimycin. By preventing the formation of monoglucosylated glycoproteins the end products are supposed to regulate the entry of newly synthesized glycoproteins into the calnexin/ calreticulin cycle [32, 33].

Complex relationship of $\alpha$-glucosidase II with the calnexin/calreticulin cycle is supplemented by no less dramatic interactions with UGGT. It is well documented that UGGT is the folding sensor due to combination of a chaperone and a glycosyltransferase activities. UGGT reactivity is strongly connected with exposed hydrophobic patches of misfolded glycoproteins on the advanced folding stages. Its glycan specificity appeared to be the highest towards $\mathrm{Man}_{9} \mathrm{GlNNAc}_{2}$, but critically declined with reducing of the mannose residues in the oligosaccharides on the glycoproteins from 8 to 7 by 50 and $85 \%$, respectively. UGGT has a strong affinity for the core of N-glycans - Man ${ }_{3} \mathrm{GlcNAc}_{2}$ and cannot recognize the oligosaccharides without core GlcNAc . Only the simultaneous recognition of a misfolded part of a protein and an appropriate high-mannose structure of a glycan leads to conformational changes of the enzyme and an addition of a glucose residue to A arm of the oligosaccharide allowing aberrant molecules to become the subjects of the calnexin/ calreticulin cycle again, but proper folded and/or assembled glycoproteins to escape the UGGT activity and proceed to their final destinations through the second reaction of $\alpha$-GII, $\alpha$-mannosidase I activity and the Golgi processing [33, 34].

Confocal immunofluorescence and high-resolution immunoelectron microscopy allowed specification of intracellular localization of $\alpha$-GII, calnexin/ calreticulin and UGGT. They were found not only in "the classical places of expectations", the rough ER including the nuclear envelope and the transitional ER, but also in the smooth ER and in the pre-Golgi intermediates. It means that quality control checkpoints are not restricted to the rough ER, but exist along the secretory pathways [35].

The next member of the quality control system, $\alpha(1,2)$-mannosidase (endomannosidase I, MAN1B1), catalyzes the removal of the terminal mannose residue from the middle branch of $\mathrm{Man}_{9} \mathrm{GlcNAc}_{2}$ and generates isomer $\mathrm{B} \mathrm{Man}{ }_{8} \mathrm{GlcNAc}_{2}$, that is the signal for ERAD. The localization of the enzyme in the peripheral and Golgi-associated pre-Golgi intermediates as well as cis and medial cisternae of the Golgi apparatus extends the system of protection against aberrant proteins at least up to the middle of the Golgi. Golgi-resident endomannosidase provides a backup mechanism for deglucosylation of glycoproteins escaping the ER [26, 27, 36, 37].

By this way the system of cell quality control can discriminate between native and nonnative proteins, leads to degrading of aberrant species through ER-associated degradation and guarantees the high fidelity of secreted and plasma membrane molecular structures [16, 38]. Until the cell can cope with alterations, any aberrant glycoproteins will not appear in functional zones (on the surface of cell membranes or outside the cell), though the products of their degradation may have already existed. So there must be a lag period between the first attempts to synthesize aberrant glycoproteins in endoplasmic reticulum and/or in Golgi apparatus and their embedding into the plasma membrane or secretion outside the cell. Therefore, some distinctive products of this non-native glycoprotein degradation could testify the beginning of a disorder much earlier than any cellular or tissue dysfunctions will appear.

Misfolded N-glycoproteins, identified during quality control analysis in the endoplasmic reticulum [39], can be exported into the cytosol via a channel containing Sec61 [40], the same complex that translocates nascent polypeptide chains into the endoplasmic reticulum, or with the help of some different proteins - Derlin family or ubiquitin protein ligases E3 (EC 6.3.2.19) [41].

In cytosol oligosaccharides are removed from glycoproteins by a cytosolic endoglucosaminidase (EC 3.2.1.96) or peptide:N-glycanase (PNGase, EC 3.5.1.52) prior to proteolysis of the deglycosylated protein by proteasomes 26S. An aberrant glyco- 
protein can be deglycosylated by an enzyme with PNGase-like activity in the ER lumen and then the free glycan and polypeptide are translocated into cytosol [42, 2, 16, 27]. A neutral chitobiase [43] or endo- $\beta-\mathrm{N}$-acetylglucosaminidase (ENGase, EC 3.2.1.96) [44, 45] removes one $\mathrm{N}$-acetylglucosamine residue from free oligosaccharides Man $_{5-8}$ Glc$\mathrm{NAc}_{2}$. The mannose residues are then cleaved by the neutral cytosolic $\alpha$-mannosidase (NAM, MAN2C1, EC 3.2.1.24) to produce a specific limit digestion product, the linier isomer $\operatorname{Man}_{5}$ GlcNAc [46]. The smaller glycans - Man $_{2-4}$ GlcNAc - were also found in the cytosol [47].The final step in the cytosolic pathway is the transport of the limit digestion oligosaccharide into lysosomes by the ATP-dependent, high-affinity oligosaccharide transporter [18, 3].

Aberrant glycoproteins can be a source of a small amount of cytosolic glucosylated oligomannose free glycans [48] that cannot be transported into the lysosome [49] and secreted by the cell [3].

Some findings, such as the increasing rate of ERAD when cytosolic $\alpha$-mannosidase is overexpressed, for example, point at a high probability of a feedback mechanism of ERAD regulation through the cytosolic FOS degradation pathway [50].

\section{Lysosomes can produce both neutral and negatively charged free oligosaccharides}

The mature glycoproteins containing highmannose, hybrid and complex glycans are turned over in lysosomes [51]. Other glycoconjugates (glycolipids, proteoglycans and glycosylphosphatidylinositol anchors) share the same fate. They are delivered to lysosomes either by endocytosis from outside the cell or by autophagy within the cell [52] and can give rise to free glycans different from the oligomannose type.

The lysosomal pathways for N-linked glycoproteins breakdown (Fig. 2) are bidirectional with proteolysis of polypeptide at one side and the sequential release of monosaccharides by exoglycosidases from the nonreducing glycan end [53].

Complete or extensive proteolysis takes place before the N-linked glycan is released from the polypeptide. The next step in the breakdown of complex or hybrid N-glycans is the removal of any fucose residues, which is catalyzed by lysosomal $\alpha$-Lfucosidase (EC 3.2.1.51). Fucose can be linked by $\alpha 1-6$ bond to the core $\mathrm{N}$-acetylglucosamine, $\alpha 1-2$, $\alpha 1-3$, or $\alpha 1-4$ bonds to $\mathrm{N}$-acetylglucosamine or $\alpha 1-2$ bond to galactose residues at the nonreducing ends of the glycans [53]. The peripheral $\alpha 1-3$ linked fucose residues are removed before the core $\alpha 1-6$ linked residues [54]. Removal of fucose allows the hydrolysis of the asparagine- $\mathrm{N}$-acetylglucosamine amide linkage by glycosylasparaginase (EC 3.5.1.26). This enzyme undergoes dimerization and autoactivation by cleavage into two subunits in the Golgi [55].

Release of the $\mathrm{N}$-acetylglucosamine residue at the reducing end of the chitobiose core can be achieved in two ways by either the $\beta-\mathrm{N}$ acetylglucosaminidase (EC 3.2.1.30) or the di- $N$ acetyl-chitobiase (EC 3.2.1.52).

Some of the glycosidases - for example, $\alpha$-neuraminidase (EC 3.2.1.18), $\beta$-galactosidase (EC 3.2.1.23), and N-acetyl- $\beta$-D-hexosaminidase (EC 3.2.1.52) - can catalyze the same linkages in other glycoconjugates, such as glycolipids or glycosaminoglycans, whereas $\alpha$-mannosidase and $\beta$-mannosidase (EC 3.2.1.25) appear to be exclusive to the glycoprotein [52].

$\mathrm{N}$-glycans of lysosomal hydrolases have mannose-6-phosphate modification, the lysosome destination recognition marker, catalyzed by two enzymes: UDP-N-acetylglucosamine-1-phosphotransferase (EC 2.7.8.17) and N-acetylglucosamine-1-phosphodiester $\alpha$-N-acetylglucosaminidase (EC 3.1.4.45). The first enzyme transfers GlcNAc1-phosphate to mannose residues on high mannose glycans in the $\alpha-1,6$ and/or $\alpha-1,3$ branch of the oligosaccharide chains [56], the second one removes the GlcNAc residues exposing Man-6-P group. That is why the second enzyme is called "uncovering enzyme". It is synthesized as an inactive proenzyme and activated by endoprotease furin (EC 3.4.21.75) in the trans-Golgi network where active "uncovering enzyme" helps to deliver soluble hydrolases to the endosomal/lysosomal compartment allowing their binding to the Man-6-P receptors [57].

Not only lysosomal hydrolases but also several nonlysosomal proteins have been shown to bear mannose-6-phosphate residues. Among them there are latent transforming growth factor $\beta 1$, leukemia inhibitory factor, proliferin, renin precursor, and T-cell activation antigen CD26. In this case the modification can facilitate interactions of secreted glycoproteins with plasma membrane receptors like for latent transforming growth factor- $\beta 1$ [58] or regulate extracellular secretion of proteins directing the modified molecules to the lysosome degradation like for leukaemia inhibitory factor [59]. So during the degradation in lysosomes some glycans with mannose-6-phosphate residues can appear. 


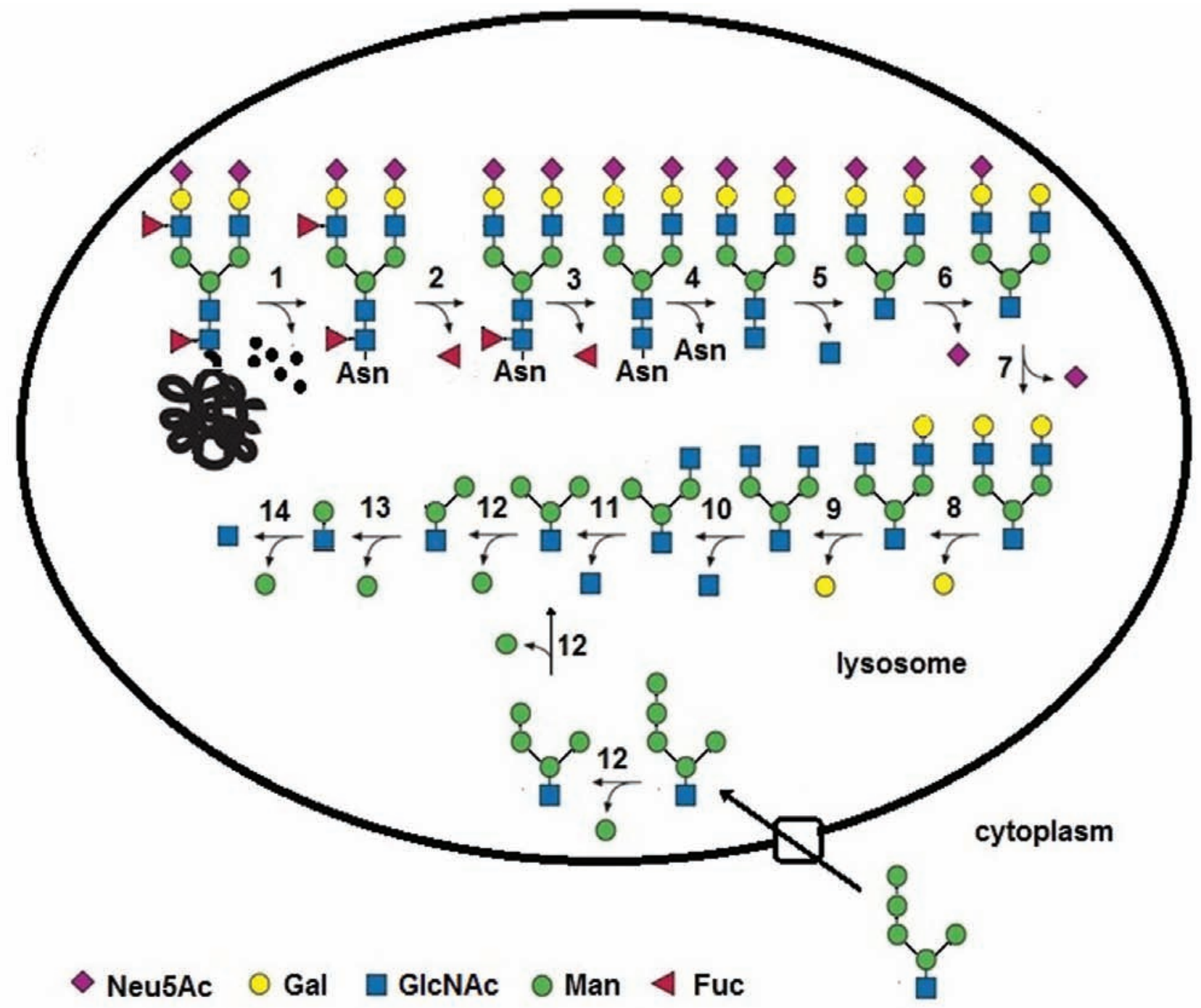

Fig. 2. Degradation of complex N-glycoprotein and appearance of FOS in lysosome: Asn - asparagine; Neu5Ac - neuraminic acid ; Gal - galactose; GlcNac - N-acetylglucosamine; Man - mannose; Fuc - fucose; 1 - proteases; 2,3 - $\alpha$-fucosidase; 4 - aspartyl- $N$-acetyl- $\beta$-D-glucosaminidase; 5 - endo- $\beta$ - $N$ acetylglucosaminidase; 6,7 - sialidase; 8,9 - $\beta$-galactosidase; 10,11 - $\beta$ - $N$-acetylhexosaminidase; 12,13 $\alpha$-mannosidase; 14 - $\beta$-mannosidase

Given GlcNAc-1-phosphotransferase is localized earlier within the Golgi than Golgi mannosidase I [60] and that the latter can direct the glycoproteins escaped ER quality control from the Golgi to ER to ERAD [26, 27], among ERAD-generated FOS there might be free glycans with GlcNAc-1-P-6-Man structures.

\section{Extracellular free oligosaccharides}

Free oligosaccharides have been investigated mostly in cultured cells. The information about their existence in culture medium is very poor. Even less is known about their presence and distribution in tissues and biological fluids with the exceptions for urine and milk.

For a long time the idea about FOS complete degradation inside the cell in norm and their appearance in urine only under disease conditions prevailed and was based on the early investigations of urinary excretions of the degradation products in the cases of so called oligosaccharidoses or lysosomal storage disorders with thin-layer chromatography $[61,62]$.

The development of more sensitive analytical procedures (high performance liquid chromatography and mass-spectrometry) allowed de- 
tecting the bulk of urine free oligosaccharides and revealing unique patterns for glycoproteinases $(\alpha$-mannosidosis, sialidosis, galactosialidosis, $\alpha$-fucosidosis, aspartylglucosaminuria), glycolipidoses (GM1 and GM2 gangliosidosis, Gaucher disease, Sandhoff disease mucolipidosis type II/III) and glycogen storage disorders (Pompe diseases) $[4,63,64]$. For example, the excess excretion of one-, two- and three-antennary high mannose-type N-glycans is a defining attribute of $\alpha$-mannosidosis, but the two-, three- and four-antennary complex-type sugar chains with polylactosamine structures at nonreducing termini are specific for GM1-gangliosidosis [65]. The only $\mathrm{N}$-acetylglucosamine residue at the reducing end of these FOS points at their cytosolic origin.

The first evidences of FOS presence in cell medium were obtained on human hepatocellular carcinoma HepG2 cells only after inhibition of lysosomal degradation of FOS and glycoproteins with a specific inhibitor concanamycin A that blocks lysosomal acidification through selective inhibition of the V-type ATPase [66].

Inhibition of FOS translocation from ER to cytosol leads to FOS moving into the cell medium by the classical secretion pathway through the Golgi. In this case the FOS have two residues of GlcNAc and may convert into complex and sialic acid-containing types due to processing in the Golgi [67].

Recently more detailed investigations of the HepG2 cell line after treatment with concanamycin A [68] revealed that about $7 \%$ of total intracellular FOS flowed from the treated cells into the medium by a way different from the classical secretion pathway through the Golgi. Without such a treatment only trace amounts of these components were detected in the culture medium. A comparison of FOS structures in different compartments of the cell with extracellular free glycans showed that all of them were of oligomannose type and about $90 \%$ of medium FOS were the components less than Man $_{7}$ GlcNAc. In the membrane bound compartments (intact lysosomes, Golgi apparatus, and ER) these structures comprise about $83 \%$, in cytosol about $70 \%$. The authors have come to the conclusion that either FOS are degraded in the medium or the secretion is selective towards smaller components and that concanamycin A courses the perturbations in lysosomal/endosomal transport allowing the content of lysosomes to be secreted without the cell damage. So the authors consider the medium FOS as products of lysosomes.
Although the statement that these cellular organelles are the exclusive origin of the medium FOS is in contradiction with the results of other studies, but the idea about the perturbations of lysosomes and their partial contribution to the extracellular pool of FOS through the cytosol is supported by diverse experimental evidence. Dramatic alteration of lysosome membrane permeabilization, its contribution to relocation of lysosomal content into the cytosol were revealed during the studies of lysosome visualization, its injury by various agents, processes of apoptosis and intracellular distribution of lysosomal enzymes in response to various stimuli [69, 70].

Indirect evidence of the lysosomal membrane permeability for oligosaccharides was the discovery of a disialobiantennary structure among free oligosaccharides glycans in a cytosolic fraction of mouse liver. The lysosome could be the only source of glycans with such a structure [47].

Targeted studies of the membrane permeability using FITC-labelled dextrans in activated human T-lymphocytes revealed size-dependant penetration of the substance to the cytosol in control cells and its substantial changing in the cells in the early stage of apoptosis caused by staurosporine. In the control FITC-labelled $10 \mathrm{kDa}$ dextrans were found in the cytosol of $9 \%$ of the cells. The dextrans of 40,70 and $250 \mathrm{kDa}$ penetrated the membrane in $3-4 \%$ of the cells. Under exposition of staurosporine the 10, 40 and $70 \mathrm{kDa}$ molecules were relocated to the cytosol in 62,41 , and $6 \%$ of the cells, respectively. The dextrans of $250 \mathrm{kDa}$ did not change their location [71].

Investigations of intracellular FOS in a bank of cancer-derived cell lines revealed a striking difference in quantity and structures of cytosolic FOS among the cells. In the cytosol of stomach cancer MKN7 and MKN45 cells unusually large amount of mono-, di-, tri- and tetra-sialoglycans - 94$96 \%$ of the total free oligosaccharides were found. Biochemical analysis defined their structures, showed that NeuAc $\alpha 2-6$ Gal $\beta 1-4 G l c N A c \beta 1-2 M a n \alpha 1-$ $3 \mathrm{Man} \beta 1-4 \mathrm{GlcNAc}$ was the most abundant of them. In addition to the sialoglycans, bisecting GlcNAc, a sialo-biantennary and fucose-containing structures, all of which cannot be derived from ERAD or dolichol-phosphate pathways, were detected. Colocalization of lysosomal enzymes in the same cytosolic fractions indicated that FOS were from lysosomes, the membranes of which were leaking. The researchers came to the conclusion that the cytosolic $\mathrm{N}$-glycans may serve as specific biomarkers for diag- 
nosis of specific tumours [72]. So, lysosome-derived cytosolic FOS might represent changes in the organelle integrity.

Intensive improvement of the protocols for analysis, using ion-exchange chromatography followed by fluorescent labelling with 2-AA (2-aminobenzoic acid), purification by lectin-affinity chromatography before separation of 2-AA-labelled FOS by HPLC, combination of enzyme digests with MALDI-TOF MS and concentration of 2-AAlabelled FOS on different stages of investigations, showed the parallels of ERAD-derived FOS behaviour in cultured cells, murine and human tissues. A treatment of mice with the imino sugar N-butyldeoxynojirimycin, an inhibitor of $\alpha$-glucosidases I and II that was used in substrate reduction therapy for Gaucher type I, Niemann-Pick type C and Sandhoff diseases (miglustat, Zavesca ${ }^{\circledR}$ ), showed a dose-dependent increase of FOS concentrations and radical changes of HPLC-profiles in all tissues and fluids. [4].

An addition of hydrophilic interaction and anion-exchange HPLC, affinity chromatography with a series of lectins to normal-phase HPLC has expanded potentialities of the methods and allowed the screening of polygenic diseases - hepatocellular carcinoma and colorectal cancer [6]. A purposeful study of human plasma FOS revealed their presence both in normal and pathological conditions (blood oncotransformation and cardiovascular diseases). They were represented by uncharged oligomannose and negatively charged species. The first group comprised the glucosylated or non-glucosylated components $\mathrm{Man}_{3-9} \mathrm{GlcNAc}_{(2)}$ with domination of species $\operatorname{Man}_{4-5} \mathrm{GlcNAc}_{(2)}$. The second group consisted of sialic acid-containing types as well as the species with the negative charge based on some different acid residues. Plasma FOS of healthy volunteers possessed featured reproducible profiles. Pathological processes changed either mostly the first group profiles (cardiovascular diseases) or the second (chronic blood cancer) or both (acute blood cancer) [73, 74].

Investigations of free oligosaccharides in biological fluids are on the earliest stage of development. The inherent complexity of oligosaccharides and the existence of various linkage isoforms make the decoding of oligosaccharide structures, representing each species in FOS profiles, the most challengeable task. An analysis of extracellular FOS in different groups of healthy people could help to understand dependence of FOS profile changes on ag- ing and genetics. FOS comparison in a wide range of illnesses would favour the selection of more specific or even unique biomarkers in each case and guarantee high fidelity of prediction.

Extracellular free oligosaccharides reflecting metabolic status, health alterations and treatment responses of the patients might be promising molecules in the search for new biomarkers of diseases and therapeutic monitoring. Detailed investigations of these oligosaccharides can suitably enrich the family of glycoconjugates studied intensively for the same purposes by opening an absolutely new perspective of early prediction of misglycosylation. Due to the system of cell quality control there must be a lag period between the first attempts to synthesize aberrant glycoproteins in endoplasmic reticulum and/or in Golgi apparatus and their embedding into the plasma membrane or secretion outside of the cell. It is among these molecules must be really the earliest biomarkers so eagerly needed for timely detection and successful treatment of numerous diseases.

Acknowledgments. The authors thank the European Molecular Biology Organization, the International Union against Cancer and Oxford Glycobiology Institute (University of Oxford, Oxford, UK) for the support to P.I.U.

\section{«ТРИ ДЖЕРЕЛА І ТРИ \\ СКЛАДОВІ ЧАСТИНИ» ВІЛЬНИХ ОЛІГОСАХАРИДІВ}

\section{І. Ю. Письменецька ${ }^{1}$, Т. Д. Баттерс ${ }^{2}$}

${ }^{1} Д У$ «Дніпропетровська медична академія», Україна; ${ }^{2}$ Інститут глікобіології Оксфордського університету, Велика Британія; e-mail: pismenetskaya@yahoo.com

Метаболізм глікопротеїнів і гліколіпідів супроводжується появою незв'язаних структурних аналогів вуглеводної частини глікокон'югатов або так званих вільних олігосахаридів. Усередині клітини існує декілька їх джерел: 1) багатоступеневий шлях $\mathrm{N}$-глікозилювання, 2) механізми контролю фолдингу протеїнів і асоційована з ЕПР деградація неправильно глікозильованих та/або неправильно згорнутих глікопротеїнів, 3) деградація зрілих глікокон'югатів у лізосомах. В огляді підсумовується відома інформація щодо шляхів появи вільних олігосахаридів у різних компартментах клітини і деталі їхноої структури 
залежно від джерела виникнення. Крім того, обговорюються дані про позаклітинні вільні олігосахариди, їх структуру та зміни за нормальних і патологічних станів.

К л ю ч о в і с л о в а: вільні олігосахариди, доліхолфосфатний цикл, асоційована 3 ЕПР деградація протеїнів, лізосомна деградація, плазма крові, сеча.

\section{«ТРИ ИСТОЧНИКА И ТРИ СОСТАВНЫЕ ЧАСТИ» СВОБОДНЫХ ОЛИГОСАХАРИДОВ}

\section{И. Ю. Письменеикая ${ }^{1}$, Т. Д. Баттерс ${ }^{2}$}

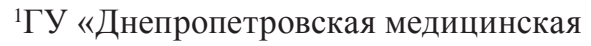 \\ академия», Украина; \\ ${ }^{2}$ Институт гликобиологии Оксфордского \\ университета, Великобритания; \\ e-mail: pismenetskaya@yahoo.com
}

Метаболизм гликопротеинов и гликолипидов сопровождается появлением несвязанных структурных аналогов углеводной части гликоконъюгатов или так называемых свободных олигосахаридов. Внутри клетки существует несколько их источников: 1) многоступенчатый путь N-гликозилирования, 2) механизмы контроля фолдинга протеинов и ассоциированная с ЭПР деградация неправильно гликозилированных и/или неправильно свернутых гликопротеинов, 3) деградация зрелых гликоконъюгатов в лизосомах. В обзоре собрана информация о путях появления свободных олигосахаридов в различных компартментах клетки и детали их структуры в зависимости от источника возникновения. Кроме того, обсуждаются данные о внеклеточных свободных олигосахаридах, их структуре и изменениях при нормальных и патологических состояниях.

Ключевы е слова: свободные олигосахариды, долихолфосфатный цикл, ассоциированная с ЭПР деградация протеинов, лизосомная деградация, плазма крови, моча.

\section{References}

1. Varki A. (ed.) Essentials of Glycobiology. Cold Spring Harbor: Cold Spring Harbor Laboratory Press, 2009. 784 p.

2. Donoso G., Herzog V., Schmitz A. Misfolded $\mathrm{BiP}$ is degraded by a proteasome-independent endoplasmic-reticulum-associated degradation pathway. Biochem. J. 2005;387:8970-903.

3. Moore S. H. E. Oligosaccharide transport: pumping waste from the ER into lysosomes. Trends Cell Biol. 1999;9:441-446.

4. Alonzi D. S., Neville D. C., Lachman R. H., Dwek R. A., Butters T. D. Glucosylated free oligosaccharides are biomarkers of endoplasmic reticulum alpha-glucosidase inhibition. Biochem. J. 2008;409(2):571-580.

5. Vleugels W., Keldermans L., Jaeken J., Butters T. D., Michalski J.-C., Matthijs G., Foulquier F. Quality control of glycoproteins bearing truncated glycans in an ALG9-defective (CDG-IL) patient. Glycobiology. 2009;19(8):910917.

6. Alonzi D. S., Su Y.-H., Butters T. D. Urinary glycan markers for disease. Biochem. Soc. Trans. 2011;39(1):393-398.

7. Pismenetskaya I. U., Butters T. D. Chromatographic profile changes of plasma free oligosaccharides in subleukemic myelosis. "Scientific Notes of Taurida V. Vernadsky National University”. Series: Biology, Chemistry. 2013;26(65), N 1:153-160. (in Russian).

8. Jones M. B., Julian N. Rosenberg J. N., Betenbaugh M. J., Krag S. S. Structure and synthesis of polyisoprenoids used in $\mathrm{N}$-glycosylation across the three domains of life. Biochim. Biophys. Acta. 2009;1790:485-494.

9. Rush J. S., Gao N., Lehrman M. A., Waechter C. J. Recycling of dolichyl monophosphate to the cytoplasmic leaflet of the endoplasmic reticulum after the cleavage of dolichyl pyrophosphate on the lumenal monolayer. J. Biol. Chem. 2008;283:4087-4093.

10. Schenk B., Fernandez F., Waechter C. J. The ins(ide) and out(side) of dolichyl phosphate biosynthesis and recycling in the endoplasmic reticulum. Glycobiology. 2001;11:61R-70R.

11. Peric D., Durrant A. C., Delenda C., Dupré T., De Lonlay P., de Baulny H. O., Pelatan C., BaderMeunier B., Danos O., Chantret I., Moore S. E. The compartmentalisation of phosphorylated free oligosaccharides in cells from a CDG Ig patient reveals a novel ER-to-cytosol translocation process. PLoS One. 2010;5;e11675.

12. Anumula K. R., Spiro R. G. Release of glucosecontaining polymannose oligosaccharides during glycoprotein biosynthesis. Studies with 
thyroid microsomal enzymes and slices. J. Biol. Chem. 1983;258:15274-15282.

13. Rosenwald A. G., Stoll J., Krag S. S. Regulation of glycosylation. Three enzymes compete for a common pool of dolichyl phosphate in vivo. J. Biol. Chem. 1990;265:14544-14553.

14. Hsu A. F., Baynes J. W., Heath E. C. The role of a dolichol-oligosaccharide as an intermediate in glycoprotein biosynthesis. Proc. Natl. Acad. Sci. USA. 1974;71:2391-2495.

15. Hoflack B., Cacan R., Verbert A. Dolichol pathway in lymphocytes from rat spleen. Influence of the glucosylation on the cleavage of dolichyl diphosphate oligosaccharides into phosphooligosaccharides. Eur. J. Biochem. 1981;117:285-290.

16. Chantret I., Moore S. E. H. Free oligosaccharide regulation during mammalian protein N-glycosylation. Glycobiology. 2008;18:210224.

17. Belard M., Cacan R., Verbert A. Characterization of an oligosaccharide-pyrophosphodolichol pyrophosphatase activity in yeast. Biochem. J. 1988;255:235-242.

18. Cacan R., Villers C., Belard M., Kaiden A., Krag S. S., Verbert A. Different fates of the oligosaccharide moieties of lipid intermediates. Glycobiology. 1992;2:127-136.

19. Grunewald S., Matthijs G., Jaeken J. Congenital disorders of glycosylation: a review. Pediatr. Res. 2002;52:618-624.

20. Vleugels W., Duvet S., Peanne R., Mir A. M. Cacan R., Michalski J. C., Matthijs G., Foulquier F. Identification of phosphorylated oligosaccharides in cells of patients with a congenital disorders of glycosylation (CDG-I). Biochimie. 2011;93:823-833.

21. Oliver G. J., Harrison J., Hemming F. W. The mannosylation of dolichol diphosphate oligosaccharides and the formation of oligosaccharides and glycoproteins in pig liver microsomal preparations. Biochem. Soc. Trans. 1975;3:666-668.

22. Hanover J. A., Lennarz W. J. Transmembrane assembly of membrane and secretory glycoproteins. Arch. Biochem. Biophys. 1981;211:1-19.

23. Harada Y., Buser R., Ngwa E. M., Hirayama H.. Aebi M., Suzuki T. Eukaryotic oligosaccharyl transferase generates free oligosaccharides during N-glycosylation. J. Biol. Chem. 2013;288(45):32673-32684.
24. Spiro M. J., Spiro R. G. Potential regulation of N-glycosylation precursor through oligosaccharide-lipid hydrolase action and glucosyltransferase-glucosidase shuttle. J. Biol. Chem. 1991;266:5311-5317.

25. Gao N., Shang J., Lehrman M. A. Analysis of glycosylation in CDG-Ia fibroblasts by fluorophore-assisted carbohydrate electrophoresis: implications for extracellular glucose and intracellular mannose 6-phosphate. J. Biol. Chem. 2005;280:17901-17909.

26. Kukushkin N. V., Alonzi D. S., Dwek R. A., Butters T. D. Demonstration that endoplasmic reticulum-associated degradation of glycoproteins can occur downstream of processing by endomannosidase. Biochem. J. 2011;438(1):133142.

27. Alonzi D. S., Kukushkin N. V., Allman S. A., Hakki Z., Williams S. J., Pierce L., Dwek R. A., Butters T. D. Glycoprotein misfolding in the endoplasmic reticulum: identification of released oligosaccharides reveals a second ER-associated degradation pathway for Golgi-retrieved proteins. Cell Mol. Life Sci. 2013;70(15):27992814.

28. Araki K., Nagata K. Protein Folding and Quality Control in the ER. Cold Spring. Harb. Perspect. Biol. 2011;3(11):a007526.

29. Hoseki J., Ushioda R., Nagata K. Mechanism and components of endoplasmic reticulum associated degradation. J. Biochem. 2010;147(1):19-25.

30. Olzmann J. A., Kopito R. R., Christianson J. C. The mammalian endoplasmic reticulumassociated degradation system. Cold Spring. Harb. Perspect. Biol. 2013;5(9):a013185.

31. Avezov E., Frenkel Z., Ehrlich M., Herscovics A., Lederkremer G. Z. Endoplasmic reticulum (ER) mannosidase $\mathrm{I}$ is compartmentalized and required for $\mathrm{N}$-Glycan trimming to $\mathrm{Man}_{5-6} \mathrm{GlcNAc}_{2}$ in glycoprotein ER-associated degradation. Mol. Biol. Cell. 2008;19:216-225.

32. Bosis E., Nachliel E., Cohen T., Takeda Y., Ito Y., Bar-Nun S., Gutman M. Endoplasmic reticulum glucosidase II is inhibited by its end products. Biochemistry. 2008;47(41):10970-10980.

33. Ito Y., Takeda Y. Deciphering the Roles of Glycan Processing in Glycoprotein Quality Control through Organic Synthesis. Biosci. Biotechnol. Biochem. 2013;77(12):2331-2338.

34. D’Alessio C., Caramelo J. J., Parodi A. J. UDP-GlC:glycoprotein glucosyltransferaseglucosidase II, the ying-yang of the ER quality 
control. Semin. Cell Dev. Biol. 2010;21(5):491499.

35. Roth J., Yam G. H.-F., Fan J., Hirano K., Gaplovska-Kysela K., Le Fourn V., Guhl B., Santimaria R., Torossi T., Ziak M., Zuber Ch. Protein quality control: the who's who, the where's and therapeutic escapes. Histochem. Cell Biol. 2008;129:163-177.

36. Pan S., Cheng X., Sifers R.N. Golgi-situated endoplasmic reticulum $\alpha-1,2$-mannosidase contributes to the retrieval of ERAD substrates through a direct interaction with $\gamma$-COP. Mol. Biol. Cell. 2013;24(8):1111-1121.

37. Rymen D., Peanne R., Millón M.B., Race V., Sturiale L., Garozzo D., Mills P., Clayton P., Asteggiano C.G., Quelhas D., Cansu A., Martins E., Nassogne M.C., GonçalvesRocha M., Topaloglu H., Jaeken J., Foulquier F., Matthijs G. MAN1B1 Deficiency: AnUnexpected CDG-II. PLoS Genet. 2013;9(12):e1003989.

38. Anelli T., Sitia R. Protein quality control in the pathway early secretory. EMBO J. 2008;27:315327.

39. Spiro R. G. Role of N-linked polymannose oligosaccharides in targeting glycoproteins for endoplasmic reticulum-associated degradation. Cell Mol. Life Sci. 2004;61:1025-1041.

40. Cacan R., Duvet S., Lablau O., Verbert A., Krag S. S. Mono-glucosylated oligomannosides are released during the degradation process of newly synthesized glycoproteins. J. Biol. Chem. 2001;276:22307-22312.

41. Hebert D. N., Bernasconi R., Molinari M. Erad substrates: which way out? Semin. Cell Dev. Biol. 2010;21:526-532.

42. Verbert A., Cacan R. Trafficking of oligomannosides released during N-glycosylation: a clearing mechanism of the rough endoplasmic reticulum. Biochim. Biophys. Acta. 1999;1473:137-146.

43. Cacan R., Dengremont C., Labiau O., Kmiecik D., Mir A. M., Verbert A. Occurrence of a cytosolic neutral chitobiase activity involved in oligomannoside degradation: a study with Madin-Darby bovine kidney (MDBK) cells. Biochem. J. 1996;313:597-602.

44. Kato T., Hatanaka K., Mega T., Hase S. Purification and characterization of endo- $\beta$ $\mathrm{N}$-acetylglucosaminidase from hen oviduct. J. Biochem. 1997;122:1167-1173.
45. Suzuki T., Yano K., Sugimoto S., Kitajima K., Lennarz W. J., Inoue S., Inoue Y., Emori Y. Endo- $\beta$-N-acetylglucosaminidase, an enzyme involved in processing of free oligosaccharides in the cytosol. Proc. Natl. Acad. Sci. USA. 2002;99:9691-9696.

46. Hirsch C., Blom D., Ploegh H. L. A role for $\mathrm{N}$-glycanase in the cytosolic turnover of glycoproteins. EMBO J. 2003;22:1036-1046.

47. Ohashi S., Iwai K., Mega T., Hase S. Quantitation and isomeric structure analysis of free oligosaccharides present in the cytosol fraction of mouse liver: detection of a free disialobiantennary oligosaccharide and glucosylated oligomannosides. J. Biochem. 1999;126:852-858.

48. Mellor H. R., Neville D. C., Harvey D. J., Platt F. M., Dwek, R. A., Butters T. D. Cellular effects of deoxynojirimycin analogues: inhibition of $\mathrm{N}$-linked oligosaccharide processing and generation of free glucosylated oligosaccharides. Biochem. J. 2004;381:867-875.

49. Saint-Pol A., Codogno P., Moore S. E. Cytosolto-lysosome transport of free polymannosetype oligosaccharides. Kinetic and specificity studies using rat liver lysosomes. J. Biol. Chem. 1999;274:13547-13555.

50. Bernon C., Carré Y., Kuokkanen E., Slomianny M. C., Mir A. M., Krzewinski F., Cacan R., Heikinheimo P., Morelle W., Michalski J. C., Foulquier F., Duvet S. Overexpression of Man2C1 leads to protein underglycosylation and upregulation of endoplasmic reticulum-associated degradation pathway. Glycobiology. 2011;21(3):363-375.

51. Yamashita K., Tachibana Y., Mihara K., Okada S., Yabuuchi H., Kobata A. Urinary oligosaccharides of mannosidosis. J. Biol. Chem. 1980;255:5126-5133.

52. Winchester B. Lysosomal metabolism of glycoproteins. Glycobiology. 2005;15(6):1R-15R.

53. Johnson S. W., Alhadeff J. A. Mammalian $\beta$-L-fucosidases. Comp. Biochem. Physiol. 1991;99B:479-488.

54. Barker C., Dell A., Rogers M., Alhadeff J. A., Winchester B. Canine $\alpha$-L-fucosidase in relation to the enzymic defect and storage products in canine fucosidosis. Biochem. J. 1988;254:861868.

55. Saarela J., Laine M., Oinonen C., von Schantz C., Jalanko A., Rouvinen J., Peltonen L. Molecular 
pathogenesis of a disease: structural consequences of aspartyglucosaminuria mutations. Hum. Molec. Genet. 2001;10:983-995.

56. Goldberg D. E., Kornfeld S. The phosphorylation of beta-glucuronidase oligosaccharides in mouse P388D1 cells. J. Biol. Chem. 1981;256:1306013067.

57. Do H., Lee W. S., Ghosh P., Hollowell T., Canfield W., Kornfeld S. Human mannose 6-phosphate-uncovering enzyme is synthesized as a proenzyme that is activated by the endoprotease furin. J. Biol. Chem. 2002;277(33):29737-29744.

58. Yang L., Tredget E. E., Ghahary A. Activation of latent transforming growth factor-betal is induced by mannose 6-phosphate/insulin-like growth factor-II receptor. Wound Repair Regen. 2000;8(6):538-548.

59. Barnes J., Lim J. M., Godard A., Blanchard F., Wells L., Steet R. Extensive mannose phosphorylation on leukemia inhibitory factor (LIF) controls its extracellular levels by multiple mechanisms. J. Biol. Chem. 2011;286(28):2485524864.

60. Lazzarino D. A., Gabel C. A. Mannose processing is an important determinant in the assembly of phosphorylated high mannosetype oligosaccharides. J. Biol. Chem. 1989;264(9):5015-5023.

61. Norden N. E., Lundblad A., Svensson S., Ockerman P. A., Autio S. A mannosecontaining trisaccharide isolated from urines of 3 patients with mannosidosis. J. Biol. Chem. 1973;248:6210-6215.

62. Peelen G. O., de Jong J. G., Wevers R. A. HPLC analysis of oligosaccharides in urine from oligosaccharidosis patients. Clin. Chem. 1994;40(6):914-921.

63. Sowell J., Wood T. Towards a selected reaction monitoring mass spectrometry fingerprint approach for the screening of oligosaccharidosis. Anal. Chim. Acta. 2011;686(1-2):102-106.

64. Xia B., Asif G., Arthur L., Pervaiz M. A., Li X., Liu R., Cummings R. D., He M. Oligosaccharide analysis in urine by maldi-tof mass spectrometry for the diagnosis of lysosomal storage diseases. Clin. Chem. 2013;59(9):1357-1368.

65. Kobata A. Exo- and endoglycosidases revisited. Proc. Jpn. Acad. Ser. B Phys. Biol. Sci. 2013;89(3):97-117.
66. Saint-Pol A., Bauvy C., Codogno P., Moore S. E. Transfer of free polymannose-type oligosaccharides from the cytosol to lysosomes in cultured human hepatocellular carcinoma HepG2 cells. J. Cell Biol. 1997;136:45-59.

67. Durrant C., Moore S. E. H. Perturbation of free oligosaccharide trafficking in endoplasmic reticulum glucosidase I-deficient and castanospermine-treated cells. Biochem. J. 2002;365:239-247.

68. Chantret I., Fasseu M., Zaoui K., Le Bizec C., SadouY.H., DupreT., Moore S.H.E.Identification of Roles for Peptide: N-Glycanase and Endo-bNAcetylglucosaminidase (Engase1p) during Protein N-Glycosylation in Human HepG2 Cells. PLOS ONE. 2010;5(7):e11734.

69. Thibodeau M. S., Giardina C., Knecht D. A., Helble J., Hubbard A. K. Silica-induced apoptosis in mouse alveolar macrophages is initiated by lysosomal enzyme activity. Toxicol. Sci. 2004;80(1):34-48.

70. Pupyshev A. B. Lysosomal membrane permeabilization as apoptogenic factor. Tsitologiia. 2011;53(4):313-324. (in Russian).

71. Bidère N., Lorenzo H. K., Carmona S., Laforge M., Harper F., Dumont C., Senik A. Cathepsin D triggers Bax activation, resulting in selective apoptosis-inducing factor (AIF) relocation in $\mathrm{T}$ lymphocytes entering the early commitment phase to apoptosis. J. Biol. Chem. 2003;78(33):31401-31411.

72. Ishizuka A., Hashimto Y., Naka R., Kinoshita M., Kakehi K., Seino J., Funakoshi Y., Suzuki T., Kameyama A., Narimatsu H. Accumulation of free complex-type N-glycans in MKN7 and MKN45 stomach cancer cells. Biochem. J. 2008;413(2):227-237.

73. Pismenetskaya I. U. Spectra detailing of blood plasma free oligosaccharides of healthy volunteers."Visnyk of the Lviv University" Series Biology. 2012;60:105-110. (in Ukrainian).

74. Pismenetskaya I. U., Butters T. D. Free oligosaccharides of human plasma as a new hunting field for disease biomarkers. Abstract book of 7th Lviv-Lublin conference of Experimental and Clinical Biochemistry. Lviv, Ukraine, 2013. P. 152. 